\title{
AROMATIC HYDROCARBON RECEPTORS IN THE IMMUNE SYSTEM: REVIEW AND HYPOTHESES
}

\author{
GYÖRGY CSABA* \\ Department of Genetics, Cell- and Immunobiology, Semmelweis University, \\ Budapest, Hungary
}

(Received: 24 October 2018; accepted: 10 December 2018)

\begin{abstract}
Ah-receptors (AhRs) recognize and bind foreign environmental molecules as well as some target hormones of other nuclear receptors. As ligands activate transcription factors, they transmit the information on the presence of these molecules by binding to the DNA, which in turn activate xenobiotic metabolism genes. Cross talk with other nuclear receptors or some non-nuclear receptors also activates or inhibits endocrine processes. Immune cells have AhRs by which they are activated for physiological (immunity) or non-physiological (allergy and autoimmunity) processes. They can be imprinted by hormonal or pseudo-hormonal (environmental) factors, which could provoke pathological alterations for life (by faulty perinatal hormonal imprinting). The variety and amount of human-made new environmental molecules (endocrine disruptors) are enormously growing, so the importance of AhR functions is also expanding.
\end{abstract}

Keywords: Ah-receptors, aromatic hydrocarbons, endocrine disruptors, allergy, autoimmunity, cross talk

\section{Introduction}

The category of polycyclic aromatic hydrocarbons (PAHs) contains diverse compounds, which consist of three or more fused aromatic rings. They are ubiquitously present in the environment as natural or artificial products. They are produced by volcanic eruptions, incomplete burning of coal, gas, wood, garbage or any organic substances as tobacco smoking, or overboiled meat. Many of them originated as product of forest wild fires, residential wood or coal burning, and mainly as exhaust from buses, trucks, and automobiles [1]. Aromatic hydrocarbons or aryl hydrocarbons are recognized and bound by the Ah-receptors (AhRs), which are present in the cytoplasm of most of the cells of human organism.

*E-mail: csaba.gyorgy@med.semmelweils-univ.hu 


\section{The Ah-Receptors (AhRs)}

The inactive AhRs are settled freely in the cytoplasm of the receptor-bearing cells, where the penetrating ligands [aromatic hydrocarbons, endocrine disruptors (EDs), as bisphenol A, etc.] can find them and later they exist together. The complex is associating with a aryl hydrocarbon receptor nuclear translocator (ARNT) and enters into the nucleus, where it finds a specific response element (DNA-binding site or sites) and induces the transcription of xenobiotic metabolism-regulating genes [2]. Later, another group of genes starts an action to terminate the process: AhR repressor is produced and heterodimerizes with the ARNT. During this process, there can also be another heterodimerization: the AhR ARNT complex could be heterodimerized with estrogen receptor alpha or beta and estrogen actions are activated. This is a suitable example of combined effects by exogeneous (PAH) and endogeneous factors. In this case, the sensor of environmental changes (the AhR) activates an endogeneous physiological process. As immune cells contain both types of receptors, combined effects can have a role in regulating physiological immune processes as well as pathological ones, including autoimmunity and allergy [3].

The aforementioned facts mean that in the family of cytoplasmic-nuclear receptors, nuclear receptor superfamily is a receptor for the PAHs. It is a basic helix-loop-helix transcription factor, which after binding of such chemicals, 2, 3, 7, 8-tetrachlorodibenzo-p-dioxin (TCDD), or some EDs enters into the nucleus of the receptor containing cell and as transcription factors in general, induces changes in gene expression, which is manifested in the response of the cell [4], to which the interactions with chaperones, various regulatory, and signaling proteins are also needed [5]. The responses are among others the disruption of the normal signal pathways, immunotoxicity, cytochrome activity changes (influence to xenobiotic metabolism), provocation of tumor development (carcinogenicity), etc [6]. This receptor can influence the immune system as immunosuppressant, in general, transmits information from cigarette smoke to diesel fumes and cool tars [7]. Considering the PAHs, as natural components were present already in the volcanic eruptions, this receptor could be one of the most ancient receptors. However, its importance was grown after the appearance of EDs in the human environment.

\section{The Endocrine Disruptors}

According to the statement of the (International) Endocrine Society "an endocrine disrupting chemical (EDC) is an exogeneous chemical or mixture of chemicals, that can interfere with any aspect of hormone action. The potential for 
deleterious effects of EDC must be considered relative to the regulation of hormone sysnthesis, secretion and actions and the variability in regulation of these events across the life cycle" [8,9]. As there is a broad spectrum of EDs, restrictions in the definition were rather problematic; however, sometimes it is supplemented with "human-made" "synthetic" artificial and natural. At present, human-made synthetic products are dominating the biological and medical research on EDC effects. This is understandable as these products are connected with our modern age and their enormously growing amount seems to be more dangerous than others, which were known 100 years ago. However, these latter disruptors sometimes exist since man is living in the earth; however, they had been categorized as "disruptors" only after the discovery of human-made disruptors, in contrast to their effects that are at least as dangerous as the effects of human-made products. This category belongs to the PAHs. EDs can also be bound by many hormone receptors (estrogen and androgen receptors, glucocorticoid receptors, etc.) influencing the binding of physiological hormones, consequently hindering or mimicking the target hormone. However, they are recognized and bound by AhRs. The effects are among others the disruption of the normal signal pathways, immunotoxicity, cytochrome activity changes (influence to xenobiotic metabolism), and provocation of tumor development (carcinogenicity), etc [6].

\section{PAHs and the Immune System}

PAHs negatively influence many systems of the human organism; however, their effects on the immune system (through AhRs) seem to be one of the most importants, considering the role of this system in the maintenance of life, by defending against infections and the disturbances of inside tissue harmony. In the immunity, there is a broad spectrum effect from the influence of immune cell development to death (apoptosis) of them to the selection of cells [10] and regulation of cytokine (IL17 and IL22) formation [11].

\section{Autoimmunity and AhRs}

Autoimmune diseases are present when the immune system, the task of which would be the defense of organism from outer invaders or inside aberrations, attacks the self components. Environmental factors have a prominent role in the provocation of the offensive, which is transmitted by the binding of small molecules to the AhRs, as ligand activated transcription factors. These small molecules could be originated from the diet, commensal flora, environmental 
pollutants, and metabolism [12, 13]. However, the AhRs, as environmental sensors are initially present in mucosal and barrier tissues [14], also can be found in many cell types of the immune system. These receptors bind EDs activating the production and transformation of immune cells [15]. DNA methylation determines the expression of genes in the immune cells, consequently the change of the methylation pattern provokes functional alterations in them, causing self-perishing actions, manifested in autoimmune diseases, e.g., in the manifestation of lupus [16]. Methylation pattern of T-cell DNA, modifies the behavior of T-cells and induces autoreactivity [16]. This could also be in the case of faulty perinatal hormonal imprinting [17]. Similar process can happen in case of a prominent ED, bisphenol A (164), which influences T- and B-cell functions, as well as macrophage and dendritic cell biology [18]. Several data were gained by laboratory exoprotein sensitization experiments; however, it seems to be valid for men, but fortunately men's AhR is less sensitive than that of rodents [19].

Lipopolysaccharides influence the expression of AhR in dendritic cells, consequently the antigen presentation, contributing the development of immune disorders. In contrast, dioxin negatively influences dendritic cell homeostasis [20], also influencing the manifestation of immune disorders. Tobacco smoke (in which aromatic hydrocarbons are present) seems to increase the manifestation of lupus [21]. Polychlorinated biphenyls, which are present in frequently consumed human diet (fish, hamburger, and poultry are the most contaminated), increase autoimmunity rates [22] as well as aromatic hydrocarbons present in atmospheric contaminations [23].

The aryl hydrocarbon receptors bind benzpyrene. This can explain why smokers have more frequently atopic dermatitis by epicutaneous sensitization (218) and autoimmune arthritis [24].

\section{Cross talk between receptors}

Cross talk between AhRs and other (nuclear) hormone receptors. As it was mentioned, the AhRs belong to the family of cytoplasmic-nuclear receptors, which are responsible for a lot of endocrine regulations (estrogen receptors, androgen receptors, corticocosterone, dezoxycorticosterone receptors, thyroid hormone receptors, peroxysome proliferator receptors, vitamin A and vitamin $\mathrm{D}$ receptors, some orphan receptors, etc.). In this receptor family, the overlaps between the originally specific receptors or dimerization with related receptors are frequent and there are also intersections and interactions in the case of aryl hydrocarbon receptors. There is an interaction between the AhR and retinoic acid 
signaling pathways, resulting in changes of retinoic acid synthesis, catabolism, transport, and secretion. AhR binding of PAHs also influences estrogen and thyroid hormone pathways [25]. Estrogen receptor alpha and beta are also targeted by PAHs, inducing some effects in the estrogen system [26]. Genes regulated by AhR-ER alpha cross talk are influenced by pesticides. In this type of cross talk, cytokine/growth factor-related signal transducers (EGF-family, TNF- $\alpha$, and TGF- $\beta$ ) are also participating [27]. They have striking anti-estrogenic activity [28]. These can be used as inhibitors of mammary tumor development [29]. AhR ligands are bound by androgen hormone receptors, and modulation of signaling by the sexual hormones is disturbed by the effects of PAHs [30]. PAH receptors are also involved in the deleterious effects of other EDs, as it is demonstrated by the effects of bisphenol A on the immune response [18]. There is a bilateral transcriptional interference between TCDD and testosterone-mediated signal transduction pathways [31]. TCDD also has a cross talk with glucocorticoid receptor [32]. These receptors are very similar: they are structurally and functionally closely related proteins [33]. The cross talk with sex-hormone signaling is an intrinsic function of AhR [34] and this is manifested in the effect of xenobiotic chemicals (e.g., pesticides) [35]. There is also a cross talk with the thyroid hormone receptors, influencing tadpole metamorphosis [36].

Cross talk with non-nuclear receptors. It is not surprising that AhRs can cross talk with other nuclear receptors [37-39], such as estrogen and andogen receptors; however, it seems to be enthusiastic that a cross talk can be supposed between the $\mathrm{AhR}$ and other non-nuclear receptors, such as prolactin and epidermal growth factor receptors [39-42]. AhR knockout mice have less follicle-stimulating hormone and luteinizing hormone amount than wild mice, and AhR is needed for normal ovulation [43]. AhR deficiency enhances insulin sensitivity, improves glucose-tolerance expression, protects against metabolic rhytmicity, and attenuates fibroblast growth factor [44-46]. As the cells of the immune system contain all of the mentioned receptors, the cross talk between the AhR and other ones supplementing the direct effect by molecules that influence the immune system forming a network regulates the whole immunity [47-50].

\section{Faulty Hormonal Imprinting of the AhR}

In the develping endocrine system, the first encounter between the developing hormone receptor and their target hormones provokes the hormonal imprinting, which has a decisive importance on the hormone recognition and binding for life. This is a physiological process, which is needed for the later normal function of the endocrine system. However, in the perinatal critical period 
molecules, similar to hormones or related molecules can be bound by the receptors, which also influence the state of the endocrine connections for life. This latter is the faulty perinatal hormonal imprinting, which could be the cause of diseases manifested in later (adult) age [51, 52]. PAHs are very strong faulty imprinters in animal experiments as well as in human cases. In rats, faulty imprinting with benzpyrene provokes the change of serotonin and endorphin content of white blood cells and mast cells [53]. Thymic glucocorticoid receptors' binding capacity was also influenced by a single (imprinting) dose neonatally [54] and combination with a phytoestrogen (genistein) does the same. Imprinting by combination with other imprinters caused the same process [55]. The effect of faulty imprinting is transmitted by mother's milk [56]. By these treatments, the microsomal enzyme system was also disturbed $[57,58]$ and the faulty imprinting by benzpyrene was also valid at growing age [59]. The immune system (immune response to infection and vaccination) was modulated [33]. Autoimmune diseases are more frequent in animals after neonatal steroid hormone treatment [60]. Some diseases are manifested after prenatal exposure of dioxin [61] and causes autoimmunity [62].

Although the mentioning of industrial EDs is more fashionable, the "traditional" disruptors are dangerous or more dangerous. These are the PAHs, produced by tools or services, which are absolutely needed for the mankind; however, the incomplete combustion is characteristic to them [63-65]. The annual emission of polycyclic organic material is about 11.000 metric tons. The residential heating is one among them that gives about $35 \%$ of PAHs and is supplemented with the agricultural open burning, which is plus $11 \%$, forest wild fires about plus $14 \%$, the mobile (auto and truck) tools plus $20 \%$, and industrial production about $7 \%$. However, it was not significant to mention the volcanic emission, which is present in a very high variable amount since the presence of life in the Earth or before it.

The cross talk between the AhRs (environmental sensors) and different receptors of the superfamily (endogeneous sensors) could influence such processes, as hormonal imprinting or tumor formation. In case of faulty imprinting [54], it was mentioned that benzpyrene imprinting was modified by the presence of genistein in the rat thymus. As thymus is a priviledged site of T-lymphocyte generetion, it has a determining role in aging and lifespan [66-68]; the cross talk between the steroid receptors and AhRs seems to be important. Stressing the thymus mainly happens by the transmission of AhRs [69] and this is wearing out the organ [70]. This imagination is supported by the protective effect of genistein to the tumorigenic effect of benzpyrene. However, this latter can also be a hormetic effect, when the diet mediated induction of glutathione S-tranferases protects mammary epithelial cells from cancerogenic effects of genotoxic carcinogens [71]. 


\section{Discussion}

It is interesting that there is a PAH - aryl hydrocarbon receptor system, which is rather peculiar, as receptors of the endocrine system are used for endogeneous hormones and the aromatic hydrocarbons are exogeneous factors, which have a "built-in" receptor for themselves, which usually transmits a negative message for the given cell and the organism. However, there is no doubt that the existence of this receptor has been considered as a full-right member of a major receptor family. This receptor can influence the immune system as immunosuppressant in general, transmitting information from cigarette smoke to diesel fumes and cool tars. Considering PAHs, as natural components are present already in the volcanic eruptions, this receptor - as it was mentioned - could be one of the most ancient receptors.

During evolution, a co-evolution of hormones and receptors can be observed. Without the target hormone, the presence of receptor is meaningless as well as the presence of hormone without the recognizing and binding structure of the receptor. However, one of the two could be present for a time, provoking the appearance of other one, forming the suitable pair. It seems to be likely that in the case of the alien-molecule recognizing - activating pair, the aromatic hydrocarbons provoked the development of their receptors in a time, when mankind has not a significant role in the formation of the environment. Nuclear hormone receptors could serve as model, or some members of the nuclear receptor family (orphan receptors) have been specialized for this aim, as aromatic hydrocarbons are lipid-soluble molecules, which can penetrate across the plasma membrane. This possibility is manifested in the similarity of structure and functional characteristics between the AhR and glucocorticoid or sexual-steroid receptors. The nuclear receptor superfamily has variable members and about 48 are known by names with specific function however with many overlappings. The function of AhR is not so specific, as it can recognize a lot of alien molecules, along with binding specific hormones. By the activation of the receptor, there is a transmission of the message to the executing system. As environmental molecules (as aromatic hydrocarbons) are dangerous to the living organisms, the main function of the AhRs is the recognition and catching them, activating the cells of the organisms to defend themselves.

Originally, the AhRs could have a modest role in the general reception process, as one of the members of nuclear receptor superfamily, because the regulation by endogeneous molecules is more important, while the environment was quiet, balanced, and stable. However, in case of the modern man, the situation basically changed. Mass of new molecules appeared in the environment forcibly introducing themselves into the organisms and only AhRs were completely able to 
recognize them, alerting the invaded cells directly or by cross talk with hormone receptors. As new molecules were increasing in the environment, the importance of AhRs has been increased - as expected - and it will reach the significant position. This is especially important in case of the immune system, which is working in the frontline of defense.

If immune cells are in the frontline of defense in animal and human organisms, it is understandable that the cells containing them are well stocked with AhRs and these instruct the physiological function of different immune cells as well as can direct them to a pathological destination, named allergic or autoimmune disease. However, immune cells are also equipped with other nuclear (estrogen, androgen, glucocorticoid, peroxysome proliferator, thyroid, and orphan) receptors, which also have regulatory roles in immune processes. In addition, there is a cross talk between them and sometimes with non-nuclear receptors, the receptorial influence could be confused and the derailment is not infrequent, causing disturbances of immunity.

Although AhRs can also recognize endogeneous molecules (hormones), their main function is the recognition of exogeneous (hormone-like) molecules, functioning as sensors of the surrounding milieu. This milieu has been altered in the last time, containing not only the natural molecules, but also a lot of synthetic ones and not only the variety of these has been increased, but also their amounts. In addition, these molecules are enormously consumed by human beings, as they are present in the urban air, in waters, drinking by us, in foods, eating by us, in our tools and medicaments and there is a continuous contamination from birth to senescence. During this period, the immune system is also continously changing, from development to decline and its built-in reactions are different in the various periods. As the reactions of the immune system are setting to a relatively stable situation, the continuous change of stimuli makes troubles, which are manifested in diseases and some of them were unknown before (e.g., irritable bowel syndrome [72, 73]).

Although AhRs are named frequently to dioxin receptors (as this molecule influences it above all), it is binding a lot of EDs (bisphenol A, which was studied above all) and their presence is reported by the sensor to different immune cells. These cells that are deeply transformed by faulty perinatal hormonal imprinting (caused by the presence of new alien molecules), and the cavalcade of different new molecules is not able to execute normal immune reactions; abnormal autoimmune reaction will develop. This backlashes to the whole endocrine system influencing the lifespan (by the effect on the thymus) and causes easily nonobservable alterations in different organs.

Hormone receptor and its target hormone together form a unit, which is able to influence an event, development of something, or production of something. 
In the organism of the ancient men, receptors and hormones could be together (as it is in case of rat observations $[74,75]$ ); however, it is not known, what could be the provocator of the development of AhRs, which are not involved in physiological processes, such as steroid or thyroid receptors. However, these materials could be the contents of volcanic emissions, or some foods, as soy isoflavones. This permits to hypothesize that genistein receptors and AhRs are related and help hydrocarbon exposure; these molecules can be demonstrated intracellularly, similar to hormones (to develop a common receptor family inside the nuclear hormone receptor family of steroid hormones, thyroid hormones, etc.). It is also possible that AhRs has an important role in the transmission of messages from different endogeneous molecules; however, the research was focused to the environmental factors to date [76]. There is also a possibility that being without specific (endocrine) function, these receptors are solely sensors of outside environmental changes [77], controlling the immune functions [78], and this could explain why are so much cross talk between them and the different hormone receptors [79]. According to some opinions, "Ah-receptors are such transcription factors, which widely express in many immune cell lineages and recognizes a range of ligands including endogeneous and dietary metabolites, microbial derivatives and xenobiotics" [80, 81]. On the whole, a tool for recognizing different message-bearing exogeneously originated or endogeneous materials, which have not specific receptors. Their function is determined by three factors: the amount of AhHs in any given cells, the abundance and potency of AhR ligands within certain tissues, and the tissue microenvironment [82]. These could be the basis of their immunomodulatory role [86], which also leads to autoimmune diseases [83-89].

Although the AhRs used to be mentioned as dioxin receptors, this does not mean that the transmission of the message of dioxin is the most important task of this receptor. About 48 named receptors belong to the nuclear (steroid) receptor superfamily, with defined functions and - as it was mentioned - there are many overlaps (cross talks) betwen them. However, it seems to be needed such a receptor that can sense other molecules, which is a universal binding site and this would be the AhR. It is stated that the AhR is present not only in vertebrates but also in invertebrates, and there is a co-evolution of ligand-activated transcription factors (as AhR) and xenobiotics-detoxifying enzymes [90]. The synthetic EDs are newcomers in our environment; however, e.g., bisphenol A, which is an outstanding member of EDs, is recognized and bound by AhRs. Although immune cells have specific receptors for a lot of hormones, they also have AhRs for non-hormonal molecules and junks, the universality of which it helps recognize such molecules and can participate in the pathology of immune system. 
Considering the sorting out function of natural selection during evolution, it is not understandable that $\mathrm{AhR}$ is present in the people of our modern age. AhR activates such properties of the cells and especially immune cells, which negatively influences life prospects. It must be supposed that in the ancient times, these receptors have some other beneficial function, which could compensate the negative effects. The environmental effects also have not been so dangerous as in our present time, so the endogeneous beneficial effect could override the negative ones. The other possibility is that the AhR is a miscarried product of genetic variations, which did not cause problems in a stable environment. However, it is causing problems in our modern time and parallelly with the increasing number, and the amount of EDs will increase the negative importance of immune cells' AhRs. Thymus is extremely sensitive to the effects transmitted by AhRs and this strongly impacts immune defense, lifespan, and autoimmune disease [67, 68, 91-95].

\section{Conflict of Interest}

The author declares no conflict of interest.

\section{References}

1. Bohácová, S., Borská, L., Fiala, Z., Andrys, C.: Effect of polycyclic aromatic hydrocarbons on the immune system. Acta Medica (Hradec Kralove) 42, 17-23 (1999).

2. Accontia, F., Pallotini, V., Marino, M.: Molecular mechanisms of action of BPA. Dose Response 13, 15593258-15610582 (2015).

3. Tian, J., Feng, Y., Fu, H., Xie, H. Q., Jiang, J. X., Zhao, B.: The aryl hydrocarbon receptor: A key bridging molecule of external and internal chemical signals. Environ Sci Technol 49, 9518-9531 (2015).

4. Safe, S., McDougal, A.: Mechanism of action and development of selective aryl hydrocarbon receptor modulators for treatment of hormone-dependent cancers (Review). Int J Oncol 20, 1123-1128 (2002).

5. Carlson, D. B., Perdew, G. H.: A dynamic role for the Ah receptor in cell signaling? Insights from a diverse group of Ah receptor interacting proteins. J Biochem Mol Toxicol 16, 317-325 (2002).

6. Mandal, P. K.: Dioxin a review of its environmental effects and its aryl hydrocarbon receptor biology. J Comp Physiol B 175, 221-230 (2005).

7. Rondelli, C. M., Campaigne Larsen, M., N'jai, A., Czuprinski, C. J., Jefcoate, C. R.: PAHs target hematopoietc lineages in bone marrow through Cyp $1 \mathrm{~b} 1$ primarily in mesenchymal stromal cells but not AhR: A reconstituted in vitro model. Stem Cells Int ID 2016, 1753491 (2016).

8. Zoeller, R. T., Brown, T. R., Doan, L. L., Gore, A. C., Skakkebaek, N. E., Soto, A. M., Woodruff, T. J., Vom Saal, F. S.: Endocrine-disrupting chemicals and public health protection: A statement of principles from The Endocrine Society. Endocrinology 153, 4097-4110 (2012). 
9. Zhang, Y., Dong, S., Wang, H., Tao, S., Hiyama, R.: Biological impact of environmental polycyclic aromatic hydrocarbons (ePAHs) as endocrine disruptors. Environ Pollut 213, 809-824 (2016).

10. Allan, L. L., Sherr, D. H.: Disruption of human plasma cell differentiation by an environmental polycyclic aromatic hydrocarbon: A mechanistic immunotoxicological study. Environ Health 9, 15 (2010).

11. Plé, C., Fan, Y., Alt Yahla, S., Vorng, H., Everaere, L., Chenivesse, C., Balsamelli, J., Azzaoul, I., de Nadai, P., Wallaert, B., Lazennec, G., Tsicopoulos, A.: Polycyclic aromatic hydrocarbons reciprocally regulate IL-22 and IL-17 cytokines in peripheral blood mononuclear cells from both healthy and asthmatic subjects. PLoS One 10, e0122372 (2015).

12. Jacobs, M. N., Lewis, D. F.: Steroid hormone receptors and dietary ligands: A selected review. Proc Nutr Soc 61, 105-122 (2002).

13. Wheeler, M. A., Rothammer, V., Quintana, F. J.: Control of immune-mediated pathology via the aryl hydrocarbon receptor. J Biol Chem 292, 12383-12389 (2017).

14. Cella, M., Colonna, M.: Aryl hydrocarbon receptor: Linking environment to immunity. Semin Immunol 27, 310-314 (2015).

15. Nishizawa, H., Imanishi, S., Manabe, N.: Effects of exposure in utero to bisphenol A on the expression of aryl hydrocarbon receptor, related factors, and xenobiotic metabolizing enzymes in murine embryos. J Reprod Dev 51, 593-605 (2005).

16. Richardson, B.: DNA methylation and autoimmune diseases. Clin Immunol 109, 72-79 (2003).

17. Csaba, G.: Immunoendocrinology: Faulty hormonal impeinting in the immune system. Acta Microbiol Immunol Hung 61, 89-106 (2014).

18. Rogers, J. A., Metz, L., Yong, V. W.: Review: Endocrine disrupting chemicals and immune responses: A focus on bisphenol A and its potential mechanisms. Mol Immunol 53, 421-430 (2013).

19. Okey, A. B., Riddick, D. S., Harper, P. A.: The Ah receptor: Mediator of the toxicity of 2, 3, 7, 8-tetrachlorodibenzo-p-dioxin (TCDD) and related compounds. Toxicol Lett 70, 1-22 (1994).

20. Bankoti, J., Burnett, A., Navarro, S., Miller, A. K., Rase, B., Shepherd, D. M.: Effects of TCDD on the fate of naive dendritic cells. Toxicol Sci 115, 422-434 (2010).

21. Costenbrader, K. H., Karlson, E. W.: Cigarette smoking and systemic lupus erythematosus: A smoking gun? Autoimmunity 38, 541-547 (2005).

22. Crinnion, W. J.: Polchlorinated biphenyls: Persistent pollutants with immunological, neurological, and endocrinological consequences. Altern Med Rev 16, 5-13 (2011).

23. O'Driscoll, C. A., Owens, L. A., Gallo, M. E., Hoffmann, E. J., Afrazi, A., Han, M., Fechner, J. H., Schauer, J. J., Bradfield, C. A., Mezrich, J. D.: Differential effects of diesel exhaust particles on T cell differentiation and autoimmune disease. Part Fibre Toxicol 15, 35 (2018).

24. Nguyen, N. T., Nakahama, T., Kishimoto, T.: Aryl hydrocarbon receptor and experimental autoimmune arthritis. Semin Immunopathol 35, 637-644 (2013).

25. Murphy, K. A., Quadro, L., White, L. A.: The intersection between the aryl hydrocarbon receptor (AhR) and retinoic acid-signaling pathways. Vitam Horm 75, 33-67 (2007).

26. Swedenborg, E., Pongratz, I., Gustafsson, J. A.: Endocrine disruptors targeting ERbeta function. Int J Androl 33, 288-297 (2010).

27. Haarmann-Stemmann, T., Bothe, H., Abel, J.: Growth factors, cytokines and their receptors as downstream targets of arylhydrocarbon receptor (AhR) signaling pathways. Biochem Pharmacol 77, 508-520 (2009). 
28. Kharat, I., Saatcioglu, F.: Antiestrogenic effects of 2, 3, 7, 8-tetrachlorodibenzo-p-dioxin are mediated by direct transcriptional interference with the liganded estrogen receptor. Cross-talk between aryl-hydrocarbon- and estrogen-mediated signaling. J Biol Chem 27, 10533-10537 (1996).

29. Safe, S., Wang, F., Porter, W., Duan, R., McDougal, A.: Ah receptor agonists as endocrine disruptors: Antiestrogenic activity and mechanisms. Toxicol Lett 102-103, 343-347 (1998).

30. Ohtake, F., Fuji-Kuriyama, Y., Kawajini, K., Kato, S.: Cross-talk of dioxin and estrogen receptor signals though the ubiquitin system. J Steroid Biochem Mol Biol 127, 102-107 (2011).

31. Jana, N. R., Sarkar, S., Ishizuka, M., Yonemoto, J., Tohyama, C., Sone, H.: Cross-talk between 2, 3, 7, 8-tetrachlorodibenzo-p-dioxin and testosterone signal transduction pathways in LNCap prostate cancer cells. Biochem Biophys Res Commun 256, 462-468 (1999).

32. Vrzal, R., Ulrichová, J., Dvorák, Z., Pávek, P.: Glucocorticoid receptor functions in HeLa cells are perturbed by 2, 3, 8, 9-tetrachlorodibenzo-p-dioxin (TCDD). Drug Metab Lett $\mathbf{1}$, 311-314 (2007).

33. Wilhelmsson, A., Wikström, A. C., Poellinger, L.: Polyanionic-binding properties of the receptor for 2, 3, 7, 8-tetrachlorodibenzo-p-dioxin. A comparison with the glucocorticoid receptor. J Biol Chem 261, 13456-13463 (1986).

34. Ohtake, F., Baba, A., Fuji-Kuriyama, Y., Kato, S.: Intrinsic AhR function underlies crosstalk of dioxins with sex hormone signaling. Biochem Biophys Res Commun 370, 541-546 (2008).

35. L'Heritier, F., Marques, M., Fauteux, M., Gaudreau, L.: Defining molecular sensors to assess long-tem effects of pesticides on carcinogenesis. Int J Mol Sci 25, 17148-17161 (2014).

36. Taft, J. D., Colonnetta, M. M., Schafer, R. E., Plick, N., Powell, W. H.: Dioxin exposure alters molecular and morphological responses to human prostate cancer cells. Toxicol Sci 161, 196-206 (2018).

37. Bonefeld-Jorgensen, E. C., Long, M., Hofmeister, M. V., Vinggaard, A. M.: Endocrinedisrupting potential of bisphenol A, bisphenol A dimethacrilate, 4-n-nonyphenol, and 4-n-octylphenol in vitro: New data and a brief review. Environ Health Perspect 116, 69-76 (2007).

38. Tian, Y., Ke, S., Thomas, T., Meeker, R. J., Gallo, M. A.: Transcriptional suppression of estrogen receptor gene expression by 2, 3, 7, 8-tetrachlorodibenzo-p-dioxin (TCDD). J Steroid Biochem Mol Biol 67, 17-24 (1998).

39. Ghotbaddini, M., Powell, J. B.: The AhR ligand, TCDD, regulates androgen receptor activity differently in androgen-sensitive versus castration-resistant human prostate cancer cells. Int J Environ Res Public Health 12, 7506-7518 (2015).

40. Umbreit, T. H., Gallo, M. A.: Physiological implications of estrogen receptor modulation by 2, 3, 7, 8-trachlorodibenzo-p-dioxin. Toxicol Lett 42, 5-14 (1988).

41. Hankinson, O.: Repression of aryl hydrocarbon receptor transcriptional activity by epidermal growth factor. Mol Interv 9, 116-118 (2009).

42. Barnett, K. R., Tomic, D., Gupta, R. K., Babus, J. K., Roby, K. F., Terranova, P. F., Flaws, J. A.: The aryl hydrocarbon receptor is required for normal gonadotropin responsiveness in the mouse ovary. Toxicol Appl Pharmacol 223, 66-72 (2007). 
43. Girer, N. G., Murray, I. A., Omiecinski, C. J., Perdew, G. H.: Hepatic aryl hydrocarbon receptor attenuates fibroblast growth factor 21 expression. J Biol Chem 291, 15378-15387 (2016).

44. Jaeger, C., Xu, C., Sun, M., Krager, S., Tischkau, S. A.: Aryl hydrocarbon-deficient mice are protected from high fat diet-induced changes in metabolic rhytms. Chronobiol Int 34, 318-336 (2017).

45. Jaeger, C., Khazaal, A. Q., Xu, C., Sun, M., Krager, S. L., Tischkau, S. A.: Aryl hydrocarbon receptor deficiency alters circadian and metabolic rhytmicity. J Biol Rhytms 32, 109-120 (2017).

46. Marsh, J. A., Scanes, C. G.: Neuroendocrine-immune interactions. Poult Sci 73, 1049-1061 (1994).

47. Berczi, I.: Pituitary hormones and immune function. Acta Paediatr 423, 70-75 (1997).

48. Klein, R.: Hormone regulation of immune homeostasis: Local or long distance? Biochem Pharmacol 56, 1-5 (1998).

49. Webster, J. I., Tonelli, L., Sternberg, E. M.: Neuroendocrine regulation of immunity. Annu Rev Immunol 20, 125-163 (2002).

50. Csaba, G.: Phylogeny and ontogeny of hormone receptors: The selection thory of receptor formation and hormonal imprinting. Biol Rev Camb Philos Soc 55, 47-63 (1980).

51. Csaba, G.: The biological basis and clinical significance of hormonal imprinting, an epigenetic process. Clin Epigenetics 2, 187-196 (2011).

52. Csaba, G., Kovács, P., Pállinger, É.: Prolonged impact of five imprinters on the serotonin content of white blood cells and mast cells of weanling rats: Outstanding effect of benzpyrene and chlorpheniramine. Cell Biol Int 28, 217-222 (2004).

53. Csaba, G., Inczefi-Gonda, Á.: Effect of a single treatment (imprinting) with genistein or combined treatment with genistein+benzpyrene on the binding capacity of glucocorticoid and estrogen receptors of adult rats. Hum Exp Toxicol 21, 231-234 (2002).

54. Csaba, G., Inczefi-Gonda, Á.: Effect of combined neeonatal imprinting by vitamin A, vitamin D3, benzpyrene and allylestrenol on adult rat thymus glucocorticoid and uterine estrogen receptors. Gen Pharmacol 29, 779-781 (1997).

55. Csaba, G., Inczefi-Gonda, Á.: Breastmilk can mediate chemical imprinting. Benzpyrene exposure during lactation reduces the thymic glucocorticoid receptor density of the offspring. Gen Pharmacol 25, 603-606 (1994).

56. Herd, J. E., Greene, F. E.: Effects of perinatal exposure to benzo(a)pyrene on the aryl hydrocarbon hydroxylase system of adult rat liver. Biol Neonate 38, 291-299 (1980).

57. Csaba, G., Mag, O., Inczefi-Gonda, Á., Szeberényi, S.: Persistent influence of neonatal 2, 3 , 7, 8-tetrachlorodibenzo-p-dioxin (TCDD) treatment on glucocorticoid receptors and on the microsomal enzyme system. J Dev Physiol 15, 337-340 (1991).

58. Csaba, G., Inczefi-Gonda, Á., Szeberényi, S.: Lasting impact of a single benzpyrene treatment in pre-natal and growing age on the thymic glucocorticoid receptors of rat. Gen Pharmacol 22, 815-818 (1991).

59. Bakker, J. M., Kavelaars, A., Kamphuis, P. J., Cobelens, P. M., van Vugt, H. H., van Bel, F., Heijnen, C. J.: Neonatal dexamethasone treatment increases susceptibility to experimental autoimmune disease in adult rats. J Immunol 165, 5932-5937 (2000).

60. Singh, N. P., Singh, U. P., Guan, H., Nagarkatti, P., Nagarkatti, M.: Prenatal exposure to TCDD triggers significant modulation of microRNA expression profile in the thymus that affects consequent gene expression. PLoS One 7, e4504 (2012). 
61. Ishimaru, N., Takagi, A., Kohahi, M., Yamada, A., Arakaki, R., Kanno, J., Hajashi, Y.: Neonatal exposure to low-dose 2, 3, 7, 8-tetrachlorodibenzo-p-dioxin causes autoimmunity due to the disruption of T cell tolerance. J Immunol 182, 6576-6588 (2009).

62. Takeda, K, Tsukue, N, Yoshida, S.: Endocrine-disrupting activity of chemicals in diesel exhaust and diesel exhaust particles. Environ Sci 11, 33-45 (2004).

63. National Research Council (USA) Committee on Pyrene and Selected Analogues: Polycyclic Aromatic Hydrocarbons from Natural and Stationary Anthropogenic Sources and Their Atmospheric Concentrations. National Academies Press, Washington, DC (1983).

64. Abdel-Shafy, H. I., Mansour, M. S. M.: A review on polycyclic aromatic hydrocarbons: Source, environmental impact, effect of human health and remediation. Egyptian J Petrol 25, 107-123 (2016).

65. Schuurman, H. J., Van Loveren, H., Rozing, J., Vos, J. G.: Chemicals trophic for the thymus: Risk for immunodeficiency and autoimmunity. Int J Immunopharmacol 14, 369-375 (1992).

66. Csaba, G.: The immunoendocrine thymus as a pacemaker of lifespan. Acta Microbiol Immunol Hung 63, 139-158 (2016).

67. Csaba, G.: The role of brain-pineal-thymus system in the determination of lifespan: The autoimmune aging theory. Adv Neuroimm Biol 6, 139-148 (2017).

68. Matsumura, F., Vogel, C. F.: Evidence supporting the hypothesis that one of the main function of aryl hydrocarbon receptor is mediation of cell stress responses. Biol Chem $\mathbf{3 8 7}$, 1189-1194 (2006).

69. Stevens, E. A., Mezrich, J. D., Bradfield, C. A.: The aryl hydrocarbon receptor. A perspective on potential roles in the immune system. Immunology 127, 299-311 (2009).

70. Steiner, C., Peters, W. H., Gallagher, E. P., Magee, P., Rowland, I., Pool-Zobel, B. L.: Genistein protects human mammary epithelial cells from benzo(a)pyrene-7, 8-dihydrol-9, 10-epoxide and 4-hydrox y-2-nonenal genotoxicity by modulating the glutathione/ glutathione S-transferase system. Carcinogenesis 28, 738-748 (2007).

71. Menees, S., Chey, W.: The gut microbiome and irritable bowel syndrome. F1000Res 7, Faculty Rev 1029 (2018).

72. Bellini, M., Gambaccini, D., Stasi, C., Urbano, M. T., Maarchi, S., Usai-Satta, P.: Irritable bowel syndrome: A disease still searching for pathogenesis, diagnosis and therapy. World $\mathrm{J}$ Gastroenterol 20, 8807-8820 (2014).

73. Stockinger, B., Di Meglio, P., Gialitakis, M., Duarte, J. H.: The aryl hydrocarbon receptor: Multitasking in the immune system. Annu Rev Immunol 32, 403-432 (2014).

74. Van Voorhis, M., Fechner, J. H., Zhang, X., Mezrich, J. D.: The aryl hydrocarbon receptor: A novel target for immunomodulation in organ transplantation. Transplantation 27, 983-990 (2013).

75. Fülöp, A. K., Csaba, G.: Impact of neonatal bemzpyrene pretreatment (imprinting) on the hepatic 3H-benzpyrene intake and output in adult rat liver. Investigation into the hepatic localization of benzpyrene in adult rats. Acta Morphol Hung 39, 279-285 (1991).

76. Csaba, G.: Hormones in the immune system and their possible role. A critical review. Acta Microbiol Immunol Hung 61, 241-260 (2014).

77. Quintana, F. J.: The aryl hydrocarbon receptor: A molecular pathway for the environmental control of the immune response. Immunology 138, 183-189 (2013).

78. Hanisch, H.: Toward understanding the role of aryl hydrocrbon receptor in the immune system: Current progress and future trends. Biomed Res Int 2014, 14 (2014). 
79. Wang, H., Wei, Y., Yu, D.: Control of lymphocyte homeostasis and effector function by the aryl hydrocarbon receptor. Int Immunopharmacol 28, 818-824 (2015).

80. Jacobs, M. N., Lewis, D. F.: Steroid hormone receptors and dietary ligands: A selected review. Proc Nutr Soc 61, 105-122 (2002).

81. Zhou, L.: AHR function in lymphocytes: Emerging concepts. Trends Immunol 37, 17-31 (2016).

82. Wheeler, M. A., Rothhammer, V., Quintana, F. J.: Control of immune-mediated pathology via the aryl hydrocarbon receptor. J Biol Chem 28, 12383-12389 (2017).

83. Baricza, E., Tamási, V., Marton, N., Buzás, E. I., Nagy, G.: The emerging role of aryl hydrocarbon receptor in the activation and differentiation of Th17 cells. Cell Mol Life Sci 73, 95-117 (2016).

84. Quintana, F. J., Sherr, D. H.: Aryl hydrocarbon receptor control of adaptive immunity. Pharmacol Rev 65, 1148-1161 (2013).

85. Esser, C., Rannug, A., Stockinger, B.: The aryl hdrocarbon receptor in immunity. Trends Immunol 30, 447-454 (2009).

86. Selmi, C., Leung, P. S., Sherr, D. H., Diaz, M., Nyland, J. F., Monestier, M., Rose, N. R., Gershwin, M. E.: Mechanisms of environmental influence on human autoimmunity: A National Institute of Environmental Health Sciences expert panel workshop. J Autoimmun 39, 272-284 (2012).

87. Quintana, F. J.: Regulation of central nervous system autoimmunity by the aryl hydrocarbon receptor. Semin Immunopathol 35, 627-635 (2013).

88. Gutierrez-Vazquez, C., Quintana, F. J.: Regulation of the immune response by the aryl hydrocarbon receptor. Immunity 48, 19-33 (2018).

89. Baker, M. E.: Xenobiotics and the evolution of multicellular animals: Emergence and diversification of ligand-activated transcription factors. Integr Comp Biol 45, 172-178 (2005).

90. Harrill, J. A., Layko, D., Nyska, A., Hukkanen, R. R., Manno, R. A., Grassetti, A., Lawson, M., Martin, G., Budinsky, R. A., Rowlands, J. C., Thomas, R. S.: Aryl hydrocarbon receptor knockout rats are insensitive to the pathological effects of repeated oral exposure of 2, 3, 7, 8-tetrachlorodibenzo-p-dioxin. J Appl Toxicol 36, 802-814 (2016).

91. Chopra, M., Schrenk, D.: Dioxin toxicity, aryl hydrocarbon receptor signaling, and apoptosis-persistent pollutants affect programmed cell death. Crit Rev Toxicol 41, 292-320 (2011).

92. Laiosa, M. D., Wyman, A., Murante, F. G., Fiore, N. C., Staples, J. E., Gasiewitz, T. A., Silverstone, A. E.: Cell proliferation arrest within intrathymic lymphocyte progenitor cells causes thymic atrophy mediated by aryl hydrocarbon receptor. J Immunol 171, 4582-4591 (2003).

93. Doi, H., Baba, T., Tohyama, C., Noha, R. A.: Functional activation of arylhydrocarbon receptor (AhR) in primary $\mathrm{T}$ cells by 2, 3, 7, 8-tetrachlorodibenzo-p-dioxin. Chemosphere 52, 655-662 (2003).

94. Hundeiker, C., Pineau, T., Cassar, G., Betensky, R. A., Gleichmann, E., Esser, C.: Thymocyte development in Ah-receptor-deficient mice is refractory to TCDD-inducible changes. Int J Immunopharmacol 21, 841-859 (1999).

95. Staples, J. E., Murante, F. G., Fiore, N. C., Gasiewitz, T. A., Silverstone, A. E.: Thymic alerations induced by 2,3,7,8-tetrachlorodibenzo-p-dioxin are strictly dependent on aryl hydrocarbon receptor activation in hemopietic cells. J immunol 160, 3844-3854 (1998). 